\title{
K-Ras stabilization by estrogen via PKCס is involved in endometrial tumorigenesis
}

\author{
Kyoung-Hwa Koo ${ }^{1,2}$, Woo-Jeong Jeong ${ }^{1,2}$, Yong-Hee Cho ${ }^{1,2}$, Jong-Chan Park ${ }^{1,2}$, Do \\ Sik Min ${ }^{1,3}$ and Kang-Yell $\mathrm{Choi}^{1,2}$ \\ ${ }^{1}$ Translational Research Center for Protein Function Control, Yonsei University, Seoul, Korea \\ ${ }^{2}$ Department of Biotechnology, College of Life Science and Biotechnology, Yonsei University, Seoul, Korea \\ ${ }^{3}$ Department of Molecular Biology, College of Natural Science, Pusan National University, Pusan, Korea \\ Correspondence to: Kang-Yell Choi, email: kychoi@yonsei.ac.kr
}

Keywords: endometrial cancer, estrogen, tumorigenesis, K-Ras, PKC $\delta$

Received: February 27, $2015 \quad$ Accepted: April 30, $2015 \quad$ Published: May 08, 2015

This is an open-access article distributed under the terms of the Creative Commons Attribution License, which permits unrestricted use, distribution, and reproduction in any medium, provided the original author and source are credited.

\section{ABSTRACT}

Estrogens are considered as a major risk factor of endometrial cancer. In this study, we identified a mechanism of tumorigenesis in which K-Ras protein is stabilized via estrogen signaling through the ER-a36 receptor. PKCס was shown to stabilize K-Ras specifically via estrogen signaling. Estrogens stabilize K-Ras via inhibition of polyubiquitylation-dependent proteasomal degradation. Estrogen-induced cellular transformation was abolished by either K-Ras or PKCठ knockdown. The role of PKCठ in estrogen-induced tumorigenesis was confirmed in a mouse xenograft model by reduction of tumors after treatment with rottlerin, a PKCठ inhibitor. Finally, levels of PKCठ correlated with that of Ras in human endometrial tumor tissues. Stabilization of K-Ras by estrogen signaling involving PKCठ up-regulation provides a potential therapeutic approach for treatment of endometrial cancer.

\section{INTRODUCTION}

Endometrial cancer (EC) is the most common type of cancer of the female reproductive system. EC can be classified into two major types: the estrogens-dependent type I endometrioid adenocarcinoma, which represents $70-80 \%$ of EC cases, and the estrogens-independent type II non-endometrioid cancers [1]. Genetic alterations commonly observed in type I EC include PTEN, K-Ras, $P I K 3 C A$, and $\beta$-catenin, whereas $p 53$ and HER-2/neu mutations are prevalent in Type II EC [2]. Because estrogens are a major risk factor for EC, progestin hormone to inhibit estrogen action has been used for treatment of EC [3]. Long-lasting unopposed estrogen exposure leads to endometrial hyperplasia, which increases the chance for development of EC [4]. In fact, EC patients retain higher circulating estrogen levels compared with healthy women $[5,6]$.

Estrogen signaling is activated by both genomic and non-genomic signaling [7]. Genomic estrogen signaling is activated by the direct actions of nuclearlocalized estrogen receptors (ERs: ER- $\alpha$ and ER- $\beta$ ), which act as transcription factors [8]. On the other hand, non-genomic signaling involves activation of estrogensignaling cascades initiated by ligand binding at the plasma membrane $[9,10]$. ER- $\alpha 36$ is a novel variant of ER- $\alpha 66$ that lacks both AF-1 and AF-2 transcriptional activation domains. ER- $\alpha 36$ is localized predominantly on the plasma membrane and mainly activates non-genomic estrogen signaling [11], and estrogen-induced proliferation of EC cells. Membrane-associated protein kinase $\mathrm{C} \delta$ (PKCס) was shown to be involved in this process [12].

$\mathrm{PKC} \delta$ is a serine/threonine kinase of the PKC family that functions in proliferation, survival, and apoptosis of cells [13]. In EC cells, total PKC activity was significantly higher than in normal endometrial tissue [14]. In addition, Ras protein levels were higher in primary endometrial adenomas than in normal endometrial tissue [15], indicating a potential role for Ras up-regulation in the development of human EC.

Recently, we found that Ras protein is stabilized via the activated Wnt/ $\beta$-catenin signaling and stabilization of oncogenic Ras by aberrant mutational activation of Wnt/ $\beta$-catenin pathway genes related with colorectal tumorigenesis [16-21]. However, other signaling pathways regulating Ras stability and its involvement with human 
cancer have not been characterized.

Here, we determined that Ras stability was increased by the natural estrogen $17 \beta$-estradiol $\left(\mathrm{E}_{2}\right)$ through ER$\alpha 36$. The K-Ras stabilization by estrogen was enhanced specifically through stabilization of PKC $\delta$. Furthermore, stabilizations of both K-Ras and PKC $\delta$ occurred through inhibition of polyubiquitylation-dependent proteasomal degradation. Estrogen-induced K-Ras stabilization via PKC $\delta$ contributes endometrial cellular transformation and endometrial tumor growth. Overall, controlling PKC $\delta$ and its binding to K-Ras could be a potential therapy for human EC.

\section{RESULTS}

\section{Estrogens stabilize Ras via ER-a36}

To investigate the effect of Ras stabilization by estrogen, we treated Ishikawa EC cells with $\mathrm{E}_{2}$. As shown by immunoblot analysis, endogenous pan-Ras protein was increased by $E_{2}$ treatment in both dose-and timedependent manners (Figure 1A and 1B). The regulation of Ras by $\mathrm{E}_{2}$ occurred at the level of protein stability rather than at the transcriptional level, as shown by the lack of significant changes in mRNA levels of $\mathrm{K}$-, N-, and H-Ras (Supplementary Figure 1A). The half-life of pan-Ras, as determined by treatment with the protein synthesis inhibitor cycloheximide (CHX), was approximately 9 hours and was mostly blocked by $\mathrm{E}_{2}$ treatment (Figure $1 \mathrm{C}$ and 1D). The Ras proteins were subjected to the degradation by polyubiquitylation-dependent proteasomes $[19,20]$, but $\mathrm{E}_{2}$ reduced the level of Ras polyubiquitylation (Figure 1E).

Previous reports indicate that ER- $\alpha 36$ is expressed on the plasma membrane of EC cells $[10,12]$ and mediates membrane-initiated estrogen signaling. To determine whether ER- $\alpha 36$ involves the stabilization of Ras by estrogen, the AN3CA EC cell line, which expresses low levels of ER- $\alpha 36$ (Supplementary Figure 1B) and does
A

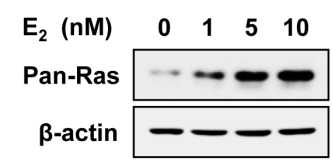

C

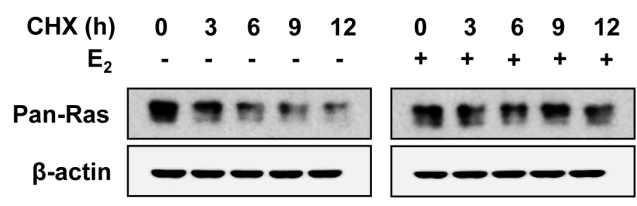

E

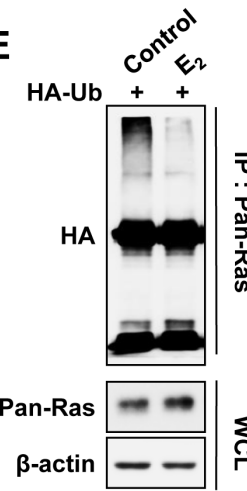

B

Time (h)

Pan-Ras

$\beta$-actin

$\begin{array}{llll}0 & 6 & 12 & 24\end{array}$

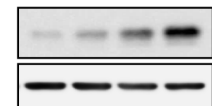

D

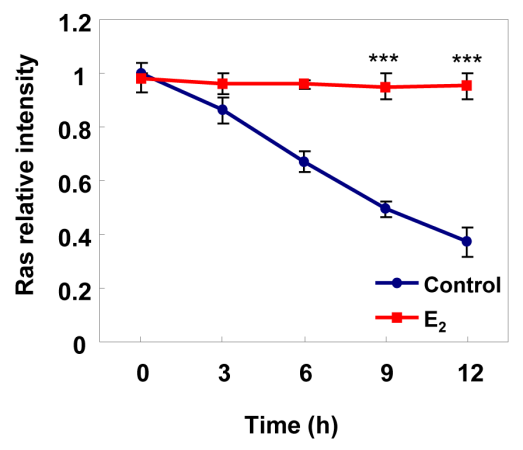

G

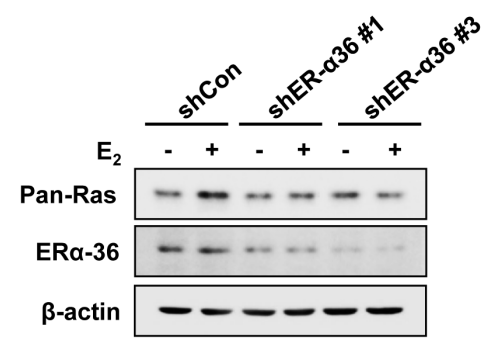

Figure 1: $\mathbf{E}_{\mathbf{2}}$ induces Ras protein stabilization via ER- $\mathbf{\alpha 3 6}$ in $\mathbf{E C}$ cells. Ishikawa cells were treated $\mathrm{E}_{2}$ in a dose- $\mathbf{A}$. and timeB. dependent manner. C. Ishikawa cells were treated CHX, $50 \mu \mathrm{g} / \mathrm{ml}$ and with/without $\mathrm{E}_{2}(10 \mathrm{nM})$ for the indicated time periods. D. The graph shows the quantification of the pan-Ras intensities of the blot on $\mathbf{C}$. relative to $\beta$-actin control. The band intensity of each protein was normalized to that of $0 \mathrm{~h}$ in $\mathrm{CHX}$ and the results represent the mean $\pm \mathrm{SD}(n=3)$. $* * * P<0.005$ compared with control. E. Ishikawa cells were transfected with pcS4-3xHA-Ub and treated with $\mathrm{E}_{2}(10 \mathrm{nM})$ for $12 \mathrm{~h}$ followed by ALLN $(25 \mu \mathrm{g} / \mathrm{ml})$ for $12 \mathrm{~h}$. Whole cell lysates (WCLs) were immunoprecipitated with anti-Ras antibody. F. AN3CA cells were transfected with pCMV-Flag-ER- $\alpha 66$, -ER- $\alpha 66-$ deleted nuclear-localized signal (mut), or -ER- $\alpha 36$ expression vectors, and after 1 day, treated with $\mathrm{E}_{2}(10 \mathrm{nM})$ for $24 \mathrm{~h}$. G. Ishikawa cells were transfected with control shRNA (shCon), ER- $\alpha 36$ shRNA ( $\operatorname{shER} \alpha-36 \# 1$ or shER $\alpha-36 \# 3$ ) and after 1 day, treated with $\mathrm{E}_{2}$ (10 nM) for $24 \mathrm{~h}$. WCLs were analyzed by western blot analysis (A-C, E-G). 
not express ER- $\alpha 66$ [22], was transiently transfected with ER- $\alpha 66$, ER- $\alpha 66-$ mut (an ER- $\alpha 66$ mutant with a deleted nuclear localization signal), or ER- $\alpha 36$ expression vectors. Levels of Ras were specifically increased by overexpressing ER- $\alpha 36$, but not ER- $\alpha 66$ or the ER- $\alpha 66$-mut, and were further increased by $\mathrm{E}_{2}$ treatment (Figure $1 \mathrm{~F}$ ). The role of ER- $\alpha 36$ in $\mathrm{E}_{2}$ - stimulated Ras stabilization was confirmed by abolishment of the $E_{2}$ effect on Ras stabilization by ER- $\alpha 36$ knockdown (Figure 1G). E 2 -BSA (bovine serum albumin), where $\mathrm{E}_{2}$ was covalently crosslinked to membrane-impermeable BSA, can only bind to the membraneous estrogen receptor [23], and cells treated with either $\mathrm{E}_{2}$ or $\mathrm{E}_{2}$-BSA similarly stabilized Ras at the same concentration (Supplementary Figure 1C).

The Ras levels were also increased by $\mathrm{E}_{2}$ treatment in MDA-MB-231 (ER- $\alpha 66$-negative breast cancer cells) and HEC1A (ER-a66-negative EC cells). However, the Ras levels were only weakly elevated by $E_{2}$ in AN3CA cells, which express low levels of ER- $\alpha 36$ (Supplementary Figure 1D). Overall, these results showed that Ras was stabilized by $\mathrm{E}_{2}$ via membrane-associated ER- $\alpha 36$.

\section{PKC反 is specifically involved in K-Ras stabilization by estrogen}

The stabilization of Ras by estrogens occurred with different isotypes including $\mathrm{K}-, \mathrm{H}-$, and N-Ras (Figure $2 \mathrm{~A}$ ), which was similar to the finding that the stability of all of these Ras isotypes were increased via the Wnt/ $\beta$ catenin signaling pathway [20]. We focused on K-Ras in the estrogen-induced Ras stabilization because K-Ras is associated with cellular transformation involving estrogens [24], and mutation or overexpression of K-Ras correlated with the development of EC [25]. As shown previously, estrogens activate the MAPK pathway via $\mathrm{PKC} \delta$ in $\mathrm{EC}$ cells [12]; therefore, we tested the involvement of $\mathrm{PKC} \delta$ in the stabilization of K-Ras by estrogen. Interestingly, we observed that protein expression of $\mathrm{PKC} \delta$, but not other $\mathrm{PKC}$ isotypes, was increased by $\mathrm{E}_{2}$ treatment of Ishikawa cells (Figure 2B; right panel shows time course data for $\mathrm{E}_{2}$ treatment). The increment of $\mathrm{PKC} \delta$ expression by $\mathrm{E}_{2}$ was not caused by change of its mRNA level as shown by RTPCR analyses (Figure 2C), but by protein stabilization by
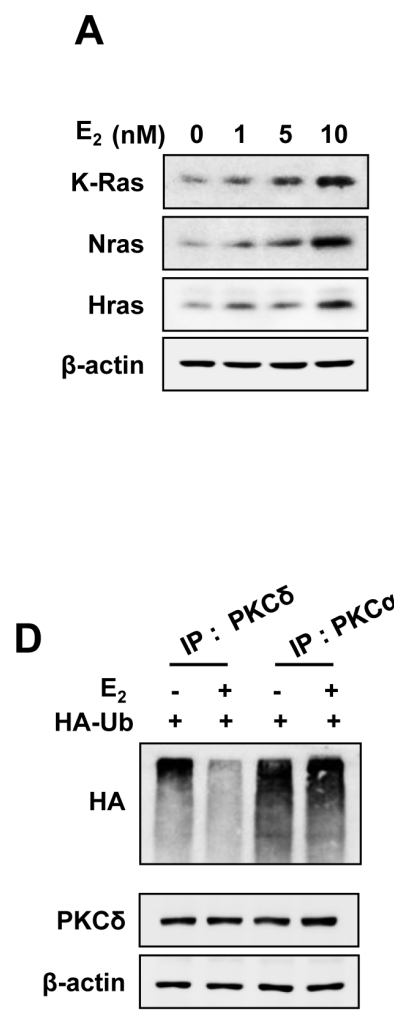

B

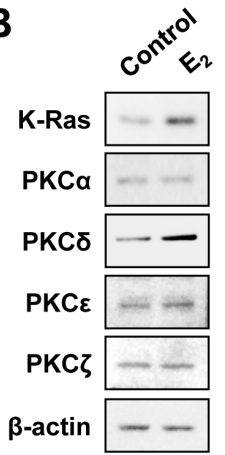

$\mathrm{E}_{2}$ 10nM

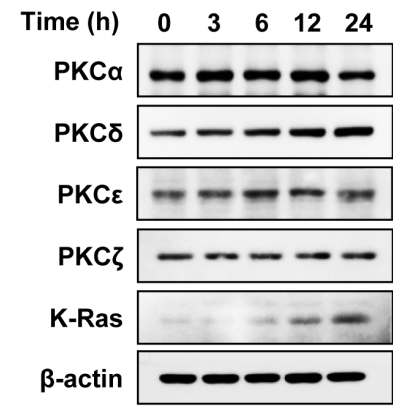

C

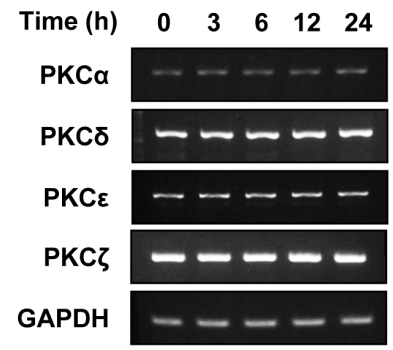

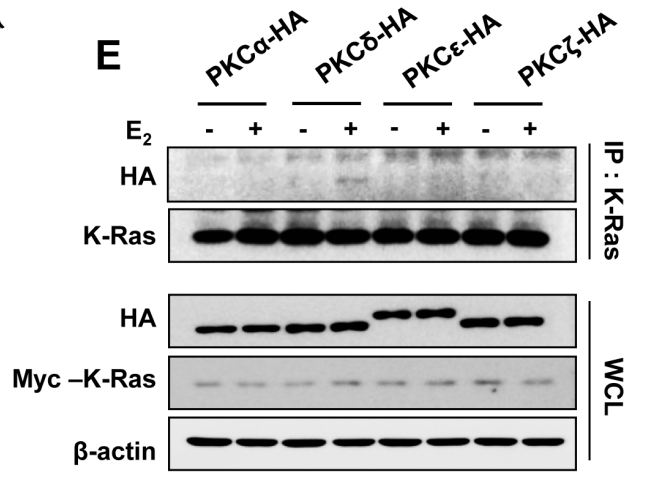

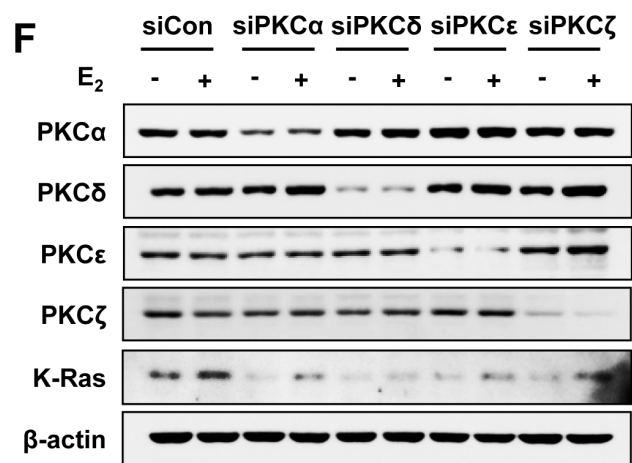

Figure 2: $\mathbf{E}_{2}$ induces K-Ras protein stabilization via PKCס. Ishikawa cells were treated with $\mathrm{E}_{2}$ in a dose- A. and time- $\mathbf{B}$. dependent manner (left panel was treated $\mathrm{E}_{2}$ for $24 \mathrm{~h}$ ). B. and $\mathbf{C}$. PKC isotypes protein $\mathbf{B}$. and mRNA C. expression levels were analyzed by western blot analysis and RT-PCR, respectively. D. Ishikawa cells were transfected with pcS4-3xHA-Ub and after 1 day, were treated with $\mathrm{E}_{2}(10 \mathrm{nM})$ for $12 \mathrm{~h}$, followed by ALLN $(25 \mu \mathrm{g} / \mathrm{ml})$ for $12 \mathrm{~h}$. WCLs were immunoprecipitated with anti-PKC $\delta$ or $-\mathrm{PKC} \alpha$ antibody. E. Ishikawa cells were transfected with pcDNA3.1-Myc-K-Ras together with pHACE- PKC $\alpha,-\mathrm{PKC} \delta,-\mathrm{PKC} \varepsilon$, or $-\mathrm{PKC} \zeta$ vector, and after 1 day, were treated with/without $\mathrm{E}_{2}(10 \mathrm{nM})$ for $30 \mathrm{~min}$. WCLs were immunoprecipitated with anti-K-Ras antibody. F. Ishikawa cells were transfected with control, PKC $\alpha, \mathrm{PKC} \delta$, PKC $\varepsilon$, or PKC $\zeta$ siRNA and after 1 day, treated with/without $\mathrm{E}_{2}$ (10 nM) for $24 \mathrm{~h}$. WCLs were analyzed by western blot analysis (A-B, D-F). 
inhibiting its polyubiquitylation (Figure 2D).

In addition, $\mathrm{PKC} \delta$, but not $\mathrm{PKC} \alpha, \mathrm{PKC} \varepsilon$, or $\mathrm{PKC} \zeta$, co-immunoprecipitated with $\mathrm{K}$-Ras in an $\mathrm{E}_{2}$-dependent manner in EC (Figure 2E), which showed the specificity of the PKC $\delta$ binding to K-Ras. The role of PKC $\delta$ in K-Ras stabilization was further confirmed by specific knockdown of PKC $\delta$, but not by knockdown of other PKC isotypes (Figure 2F).

The basal level of PKC $\delta$ expression in $\mathrm{EC}$ cell lines such as Ishikawa and HEC1A was higher than in the normal endometrial epithelial cell line EM-E6/E7/hTERT. Moreover, levels of PKC $\delta$ expression were proportional to the expression of pan-Ras and K-Ras as well as ER- $\alpha 36$
(Supplementary Figure 1B). By comparison, after specific knockdown of PKC $\delta$ in Ishikawa and HEC1A cells, which normally express high levels of both PKC $\delta$ and Ras, $\mathrm{K}$-Ras expression was decreased compared to control (Supplementary Figure 2A). In addition, inhibition of de novo protein synthesis resulted in destabilization of K-Ras, which was significantly enhanced by PKC $\delta$ knockdown $\left(\mathrm{t}_{1 / 2}=3 \mathrm{~h}\right.$ vs. $9 \mathrm{~h}$ ) (Supplementary Figure 2B and 2C). In contrast with the knockdown effect, endogenous K-Ras levels were significantly increased by overexpression of PKC $\delta$ in RL95-2 and AN3CA cells, which normally express low levels of PKC $\delta$ (Supplementary Figure 2D).

We have shown that $\mathrm{E}_{2}$ induced $\mathrm{K}$-Ras stabilization

A

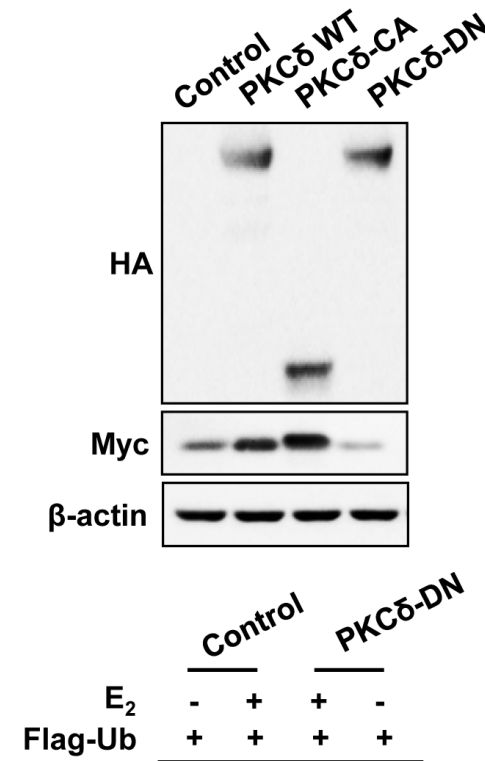

B

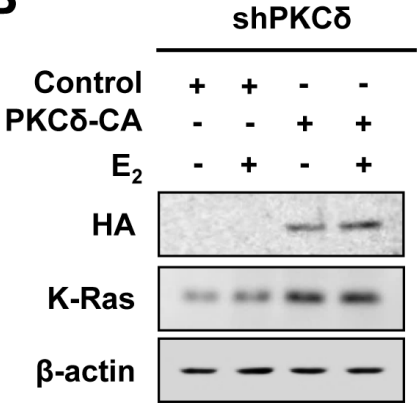

$\mathbf{E}$

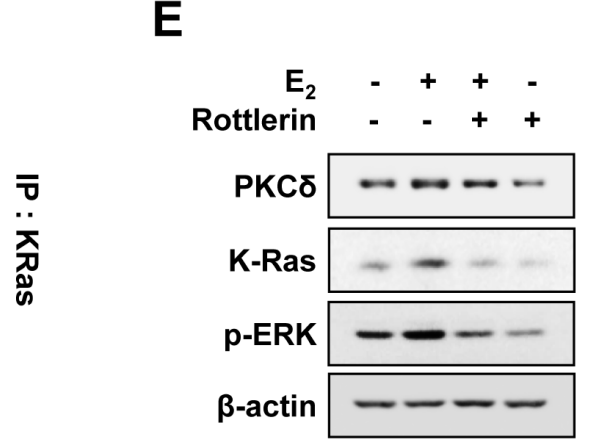

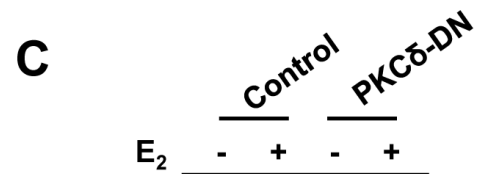

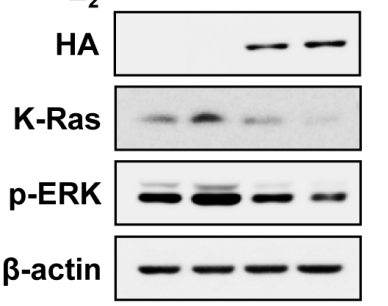

$\mathbf{F}$

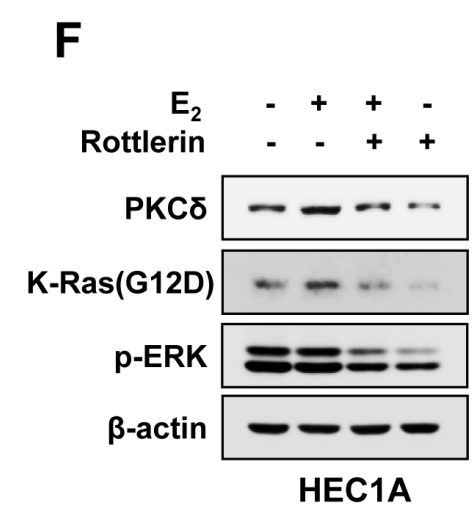

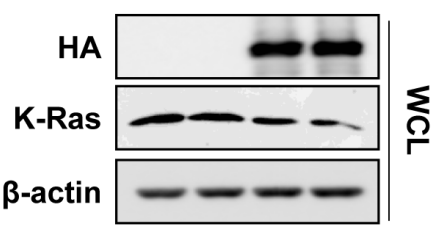

Figure 3: The effect of PKC $\boldsymbol{\delta}$ activity on K-Ras stabilization by $\mathbf{E}_{2}$. A. Ishikawa cells were transfected with pcDNA3.1-Myc$\mathrm{K}-\mathrm{Ras}$ together with $\mathrm{pHACE}-\mathrm{PKC} \delta-\mathrm{WT}, \mathrm{PKC} \delta-\mathrm{CA}$, or PKC $\delta$-DN. B. The stable shPKC $\delta$ Ishikawa cells were transfected with pHACE or pHACE-PKC $\delta$-CA and treated with $\mathrm{E}_{2}(10 \mathrm{nM})$ for $24 \mathrm{~h}$ after 1 day. C. Ishikawa cells were transfected with pHACE or pHACE-PKC $\delta$-DN and after 1 day, were treated with $\mathrm{E}_{2}(10 \mathrm{nM})$ for $24 \mathrm{~h}$. D. Ishikawa cells were co-transfected pcS4-3xflag-Ub and pHACE-PKC $\delta$-DN, and after 1 day, the cells were treated with $\mathrm{E}_{2}(10 \mathrm{nM})$ for $12 \mathrm{~h}$ followed by ALLN $(25 \mu \mathrm{g} / \mathrm{ml})$ for $12 \mathrm{~h}$. WCLs were immunoprecipitated with anti-K-Ras antibody. Ishikawa cells E. and HEC1A cells F. were treated with $\mathrm{E}_{2}(10 \mathrm{nM})$ for $6 \mathrm{~h}$ followed by rottlerin $(2 \mu \mathrm{M})$ for $18 \mathrm{~h}$. WCLs were analyzed by western blot analysis (A-F). 
occurs through ER- $\alpha 36$ and PKC $\delta$. To further elucidate the relationship between ER- $\alpha 36$ and PKC $\delta$ in K-Ras stabilization by estrogen, we examined whether K-Ras binds to ER- $\alpha 36$ or PKC $\delta$. Results of immunoprecipitation experiments showed that PKC $\delta$ was detected with Myctagged K-Ras after $\mathrm{E}_{2}$ treatment and that association between K-Ras and PKC $\delta$ was significantly enhanced in cells where ER- $\alpha 36$ was overexpressed (Supplementary Figure 3A). In control cells, but not in shPKC $\delta$ cells, $\mathrm{K}-\mathrm{Ras}$ levels were increased by overexpression of ER$\alpha 36$ (Supplementary Figure 3B). However, the effect of $\mathrm{PKC} \delta$ overexpression largely remained even after ER- $\alpha 36$ knockdown (Supplementary Figure 3C).

The abundance of endogenous K-Ras was reduced by knockdown of PKC $\delta$ and further knockdown of ER$\alpha 36$ did not decrease K-Ras protein level (Supplementary Figure 3D). These results confirm that PKC $\delta$ functions downstream of ER- $\alpha 36$. Our results show that K-Ras

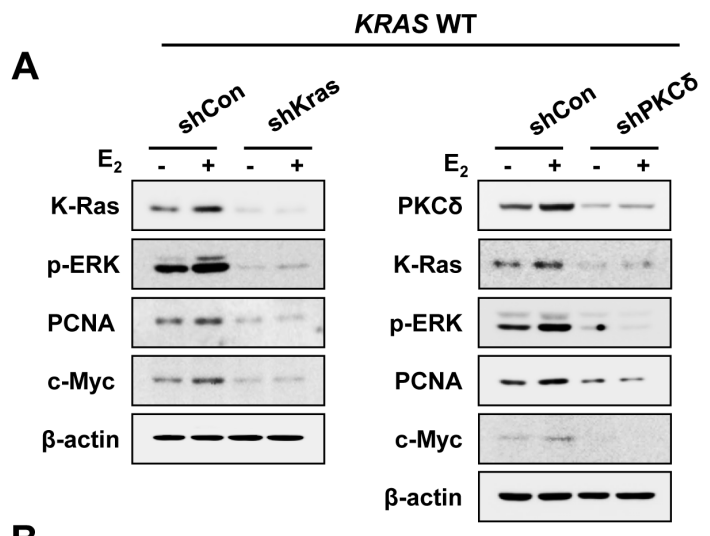

B
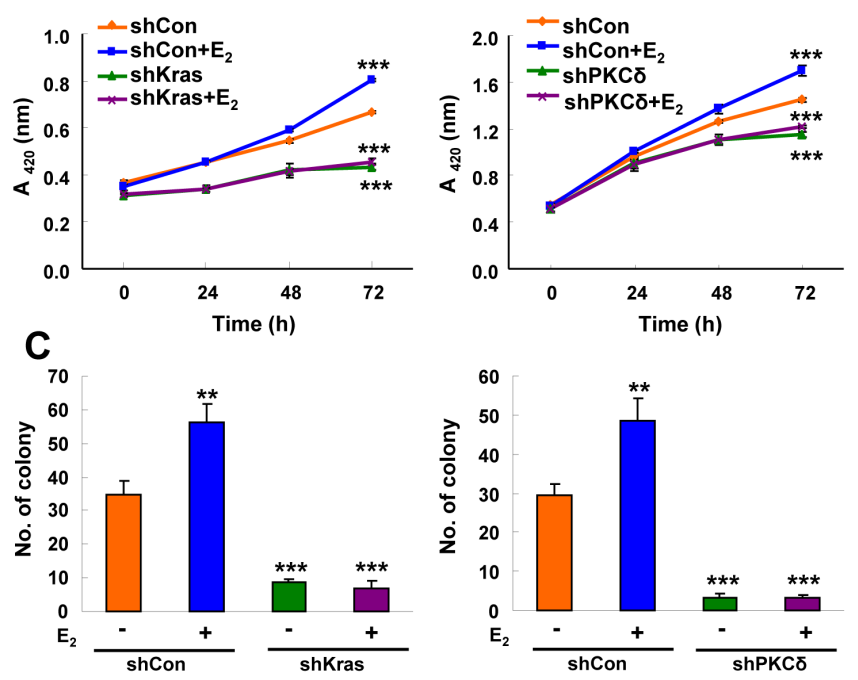

protein is stabilized by estrogen via ER- $\alpha 36$ and that association occurred through enhancement of PKC $\delta$ binding affinity to K-Ras (Figure 7).

\section{$P K C \delta$ activity is essential for K-Ras stabilization by estrogen}

Myc-tagged K-Ras was increased by overexpression of wild-type $\mathrm{PKC} \delta$, which was further increased and decreased by overexpression of catalytically active (PKC $\delta-\mathrm{CA})$ and dominant-negative $\mathrm{PKC} \delta(\mathrm{PKC} \delta-\mathrm{DN})$, respectively (Figure 3A). Levels of endogenous K-Ras in shPKC $\delta$-Ishikawa cells were significantly increased by overexpression of catalytically active $\mathrm{PKC} \delta$ regardless of $\mathrm{E}_{2}$ treatment (Figure 3B).

In addition, $\mathrm{E}_{2}$-induced $\mathrm{K}$-Ras stabilization was abolished by overexpression of dominant-negative $\mathrm{PKC} \delta$, and the activation status of ERK was proportional to the

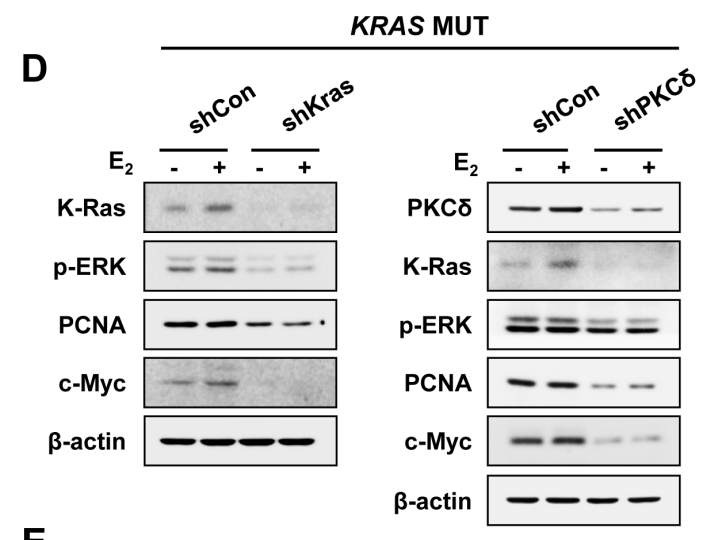

E
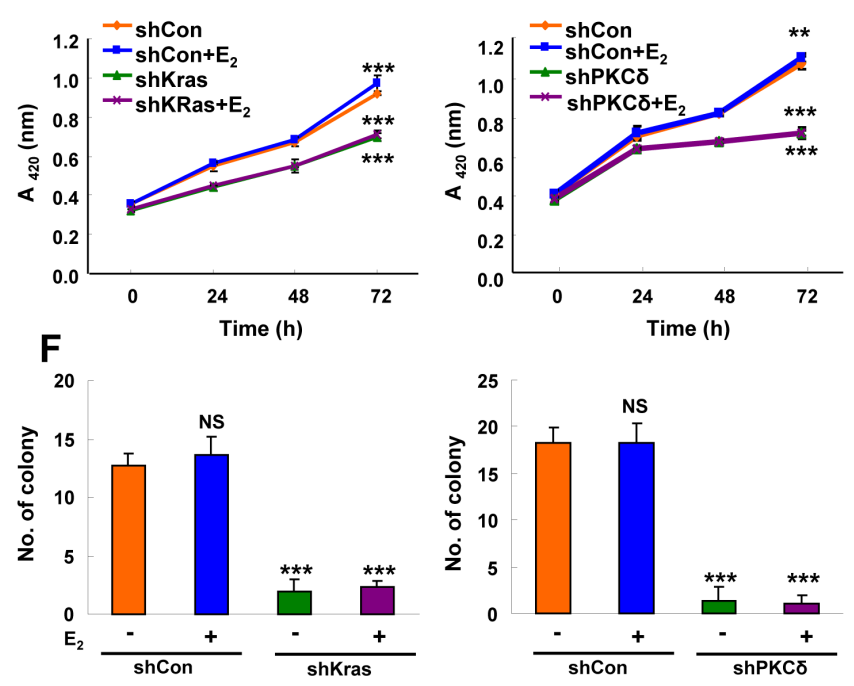

Figure 4: The effects of PKC $\delta$ or K-Ras knockdown on $\mathrm{E}_{2}$-induced Ras-ERK pathway activation and cellular transformation. A., B., and C. Stable shCon, shK-Ras, or shPKC $\delta$ Ishikawa cells. D., E., and F. Stable shCon, shK-Ras, or shPKC $\delta$ HEC1A cells. (A and D) Cells were treated with/without $\mathrm{E}_{2}(10 \mathrm{nM})$ for $24 \mathrm{~h}$. WCLs were analyzed by western blot analysis. (B and E) MTT assays were performed every $24 \mathrm{~h}$ for $72 \mathrm{~h}$ after $\mathrm{E}_{2}(10 \mathrm{nM})$ treatment. The results represent the mean $\pm \mathrm{SD}(n=3)$. $* * P<0.01$ and $* * * P<0.005$. (C and F) Cells were treated with $\mathrm{E}_{2}(10 \mathrm{nM})$ every 3 days for 14 days. Colony numbers were counted. The results represent the mean $\pm \mathrm{SD}(n=3) .{ }^{* *} P<0.01$ and $* * * P<0.005$ compared with control. $\mathrm{NS}=$ not significant compared with control. 
levels of K-Ras (Figure 3C).

We confirmed that the mechanism of K-Ras stabilization by $\mathrm{E}_{2}$ requiring $\mathrm{PKC} \delta$ activity was through inhibition of polyubiquitylation-dependent proteasomal degradation by showing increment of $\mathrm{K}$-Ras polyubiquitylation by $\mathrm{PKC} \delta$-DN overexpression, independent of $E_{2}$ treatment (Figure 3D). Finally, the role of PKC $\delta$ activity in K-Ras stabilization was confirmed by abolishment of $\mathrm{E}_{2}$-induced K-Ras stabilization by the PKC $\delta$ specific inhibitor, Rottlerin (Figure 3E). We also found that the stability of the oncogenic mutant K-Ras (G12D) was increased by estrogens via PKC $\delta$ as shown by rottlerin treatment (Figure $3 \mathrm{~F}$ ). In summary, $\mathrm{PKC} \delta$ activity is involved in the increment of K-Ras stability by estrogen signaling.

\section{PKCס-stimulated K-Ras stabilization by estrogen is involved in transformation of $\mathrm{EC}$ cells}

To understand role of K-Ras stabilization via $\mathrm{PKC} \delta$ in the transformation of EC cells, we generated cells with stable knockdown of K-Ras or PKC $\delta$ by infection with shK-Ras and shPKC $\delta$ lentiviruses, respectively. ERK activity and expression of PCNA and c-Myc were increased along with $\mathrm{K}$-Ras stabilization by $\mathrm{E}_{2}$ in Ishikawa cells, and these $\mathrm{E}_{2}$ effects were abolished in shK-Ras cells (Figure 4A, left). Similar results were observed in shPKC $\delta$ cells (Figure 4A, right). Cell proliferation was increased by $43 \%$ at 72 hours after $\mathrm{E}_{2}$ treatment, and the $\mathrm{E}_{2}$-induced cell proliferation was totally abolished by knockdown of K-Ras or PKC $\delta$ and (Figure 4B). Similarly, numbers of transforming foci were significantly increased by $E_{2}$ treatment, and basal as well as the $E_{2}$-induced foci formation were abolished in the cells with knockdown of $\mathrm{K}-\mathrm{Ras}$ or PKC $\delta$ (Figure 4C and Supplementary Figure $4 \mathrm{~A})$.

\section{D}

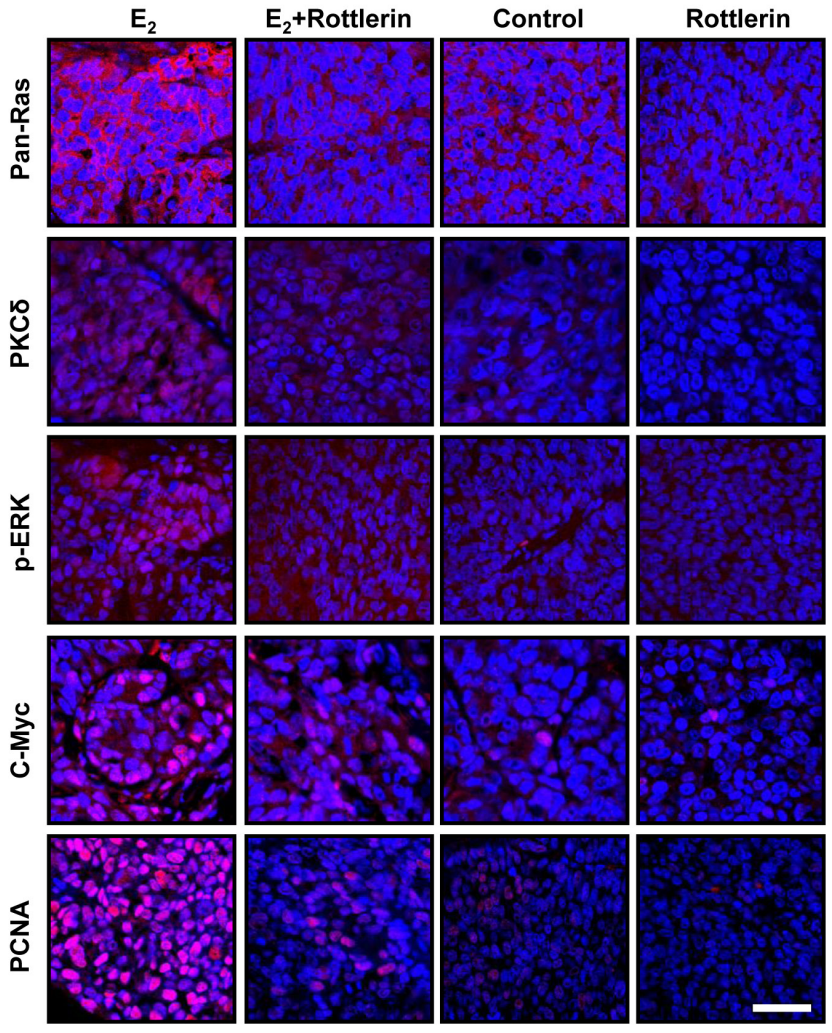

A

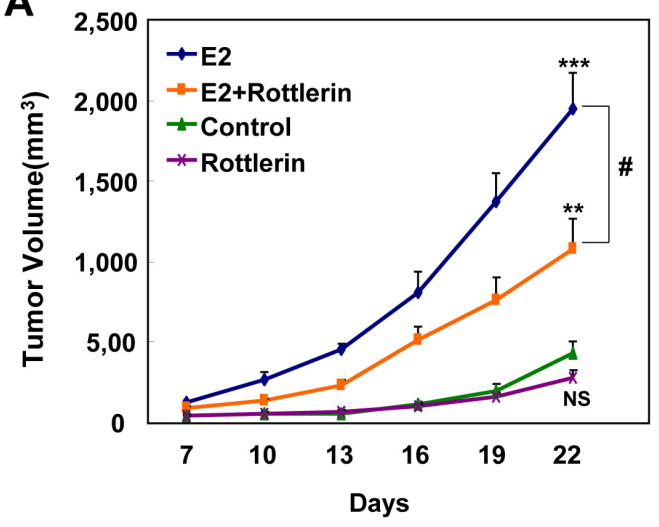

B

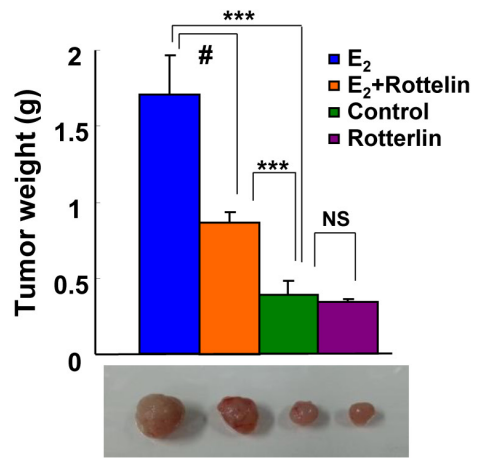

C

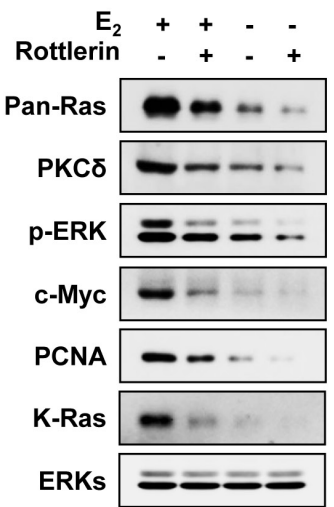

Figure 5: Effects of a $\mathrm{PKC} \delta$ inhibitor on $\mathrm{E}_{2}$-induced tumor growth, and $\mathrm{PKC} \delta$ and $\mathrm{K}$-Ras stabilization in the mouse xenograft model. A. Ishikawa cells were subcutaneously injected along with a $1.7 \mathrm{mg} / 60$-day $\mathrm{E}_{2}$ pellet into athymic female nude mice. Two days later, rottlerin was administered intraperitoneally at $5 \mathrm{mg} / \mathrm{kg}$ once daily. Tumor size was measured with Vernier calipers every 3 days. B. The mice were sacrificed after 22 days, and tumor weights were measured by an electronic balance. The results represent the mean $\pm \mathrm{SD}(n=8) . * * P<0.01, * * * P<0.005, \mathrm{NS}=$ not significant, and $\#, P<0.01 \mathrm{E}_{2} \mathrm{vs}_{2}+$ rottlerin. The results represent the mean $\pm \mathrm{SD}$. Gross images from representative tumors are shown at the bottom. C. WCLs were analyzed by western blot analysis. D. Paraformaldehydefixed paraffin-embedded sections were subjected to immunofluorescence analyses and images were captured by laser scanning confocal microscopy. Scale bar, $40 \mu \mathrm{m}$. 
The oncogenic K-Ras mutant was also stabilized by $\mathrm{E}_{2}$ treatment, but this was abolished, together with reduction of ERK activity, by knockdown of the mutant $\mathrm{K}-\mathrm{Ras}$ or PKC $\delta$ (Figure 4D). Cell proliferation and transforming focus formation were not increased by $\mathrm{E}_{2}$ in HEC1A cells harboring mutant $K$-Ras; however, those were significantly reduced by K-Ras or PKC $\delta$ knockdown (Figure 4E, 4F and Supplementary Figure 4B). Consequently, our results showed that $\mathrm{PKC} \delta$ is important for proliferation and transformation induced by K-Ras stabilization.

\section{PKCס inhibitor suppresses $\mathrm{E}_{2}$-induced K-Ras stabilization and tumor growth in a mouse xenograft model}

To identify the role of K-Ras stabilization involving $\mathrm{PKC} \delta$ in EC tumorigenesis in vivo, we examined whether inhibition of PKC $\delta$ blocked estrogen-induced tumor growth of EC cells in a mouse xenograft model. We used Ishikawa cells harboring wild-type K-Ras to monitor the unique effect of stabilization, and not the effect of oncogenic activation of K-Ras, by estrogens on tumor growth. Tumor growth was monitored either by volume or weight, and was significantly increased in the xenografted mice injected with cells treated with the $\mathrm{E}_{2}$ pellet. The volumes and weights of tumors for $\mathrm{E}_{2}$-induced xenograft were significantly reduced by co-treatment with the PKC $\delta$ inhibitor rottlerin. Furthermore, tumor volume and weight were reduced by $55 \%$ and $50 \%$, respectively, in mice cotreated with rottlerin (Figure 5A and 5B).

To verify whether the mechanism for $\mathrm{E}_{2}$-induced Ras stabilization involving $\mathrm{PKC} \delta$ was involved in tumorigenesis in vivo, we monitored levels of $\mathrm{PKC} \delta$, panRas, p-ERK, and c-Myc in the tumors by both western blot and immunofluorescence analyses. The levels of panRas, $\mathrm{PKC} \delta$, and $\mathrm{p}$-ERK were increased by $\mathrm{E}_{2}$ but blocked by rottlerin (Figure $5 \mathrm{C}$ and $5 \mathrm{D}$ ). The levels of PCNA correlated with pan-Ras and PKC $\delta$ by western blot and

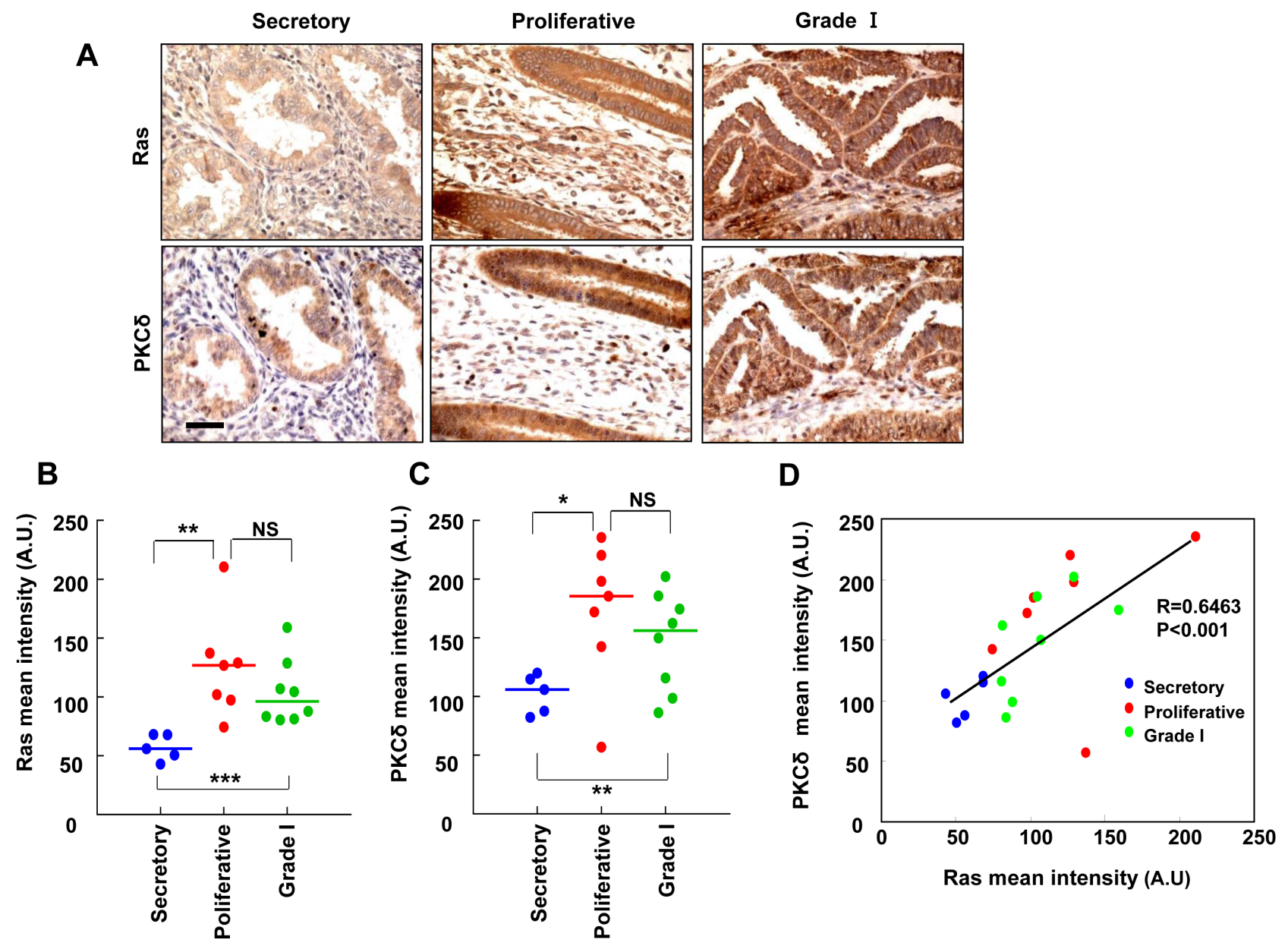

Figure 6: The relative quantification of Ras and PKC $\delta$ protein levels in human endometrial tissues. A. Ras or PKC $\delta$ in TMA serial sections of normal endometrium (secretory and proliferative stages) and endometrial carcinoma (Grade I) were evaluated by immunohistochemical analyses and microscopy. Scale bar, $40 \mu \mathrm{m}$. B. and C. Quantitative analyses of immunohistochemical staining were performed using HistoQuest software. The results represent the mean $\pm \mathrm{SD}$. ${ }^{*} P<0.05, * * P<0.01$ and $* * * P<0.005$, and NS $=$ not significant. D. The correlation between Ras and PKC $\delta$ protein levels was analyzed by Pearson's correlation analysis with a coefficient of $0.6463(p<0.001)$. 
immunofluorescence analyses. Therefore, we found that $\mathrm{PKC} \delta$ stimulates EC tumorigenesis by $\mathrm{E}_{2}$-induced $\mathrm{K}$-Ras stabilization in vivo.

\section{The expression of Ras and PKC $\delta$ was up- regulated in human endometrial carcinoma}

To investigate the involvement of Ras and PKC $\delta$ in human EC, we used tissue microarrays from 12 cases of normal tissue ( 5 secretory stage and 7 proliferative, respectively) and 8 cases of grade I tumors. The normal tissue arrays included samples from both secretory stage and proliferative endometrium to check variation due to the menstrual cycle. Immunohistochemistry for pan-Ras and $\mathrm{PKC} \delta$ was performed, and representative images of the staining are presented (Figure 6A). Both Ras and $\mathrm{PKC} \delta$ expression was more abundant in the grade I endometrial carcinoma and proliferative phase of normal endometrium compared with the secretory phase of normal endometrium (Figure 6B and 6C). The intensities of Ras and PKC $\delta$ staining showed similar patterns in the epithelium of the endometrial glands, and positive correlation was shown for Ras and PKC $\delta$ in between proliferative phase of normal endometrium and grade I endometrial carcinoma (Figure 6D).

\section{DISCUSSION}

Ras proteins are important for various cellular functions including cell proliferation, differentiation, and survival. The regulation of Ras proteins and their activities are controlled via switching of their GDP and GTP binding forms by extra- and intra-cellular signaling. Activated GTP-bound Ras proteins increase proliferation signaling through downstream pathways including the Raf-ERK and PI3 kinase-Akt pathways [26]. Aberrant activation of Ras proteins by mutations that fix Ras as a GTP binding form promotes various human tumors. K-Ras mutations are most common among the Ras isotypes and are found in various human cancers at frequencies as high as $40-50 \%$ in colorectal cancer and $90 \%$ in pancreatic cancer [27, 28]. The $K$-Ras mutation is found at a much lower frequency of about $15 \%$ in human EC [29].

Ras activity is mainly controlled by the GDP-GTP switch, but it also controlled by membrane localization [30]. Recently, the stabilization of Ras protein has been shown as an alternative mechanism for Ras activity control. Ras protein stability increased by the Wnt $/ \beta$ catenin signaling has been shown to be directly involved in colorectal tumorigenesis and cancer stem cell activation [19-21]. In addition, up-regulation of Ras has been observed in several cancers including colorectal and breast $[31,32]$, and its increased expression has been associated

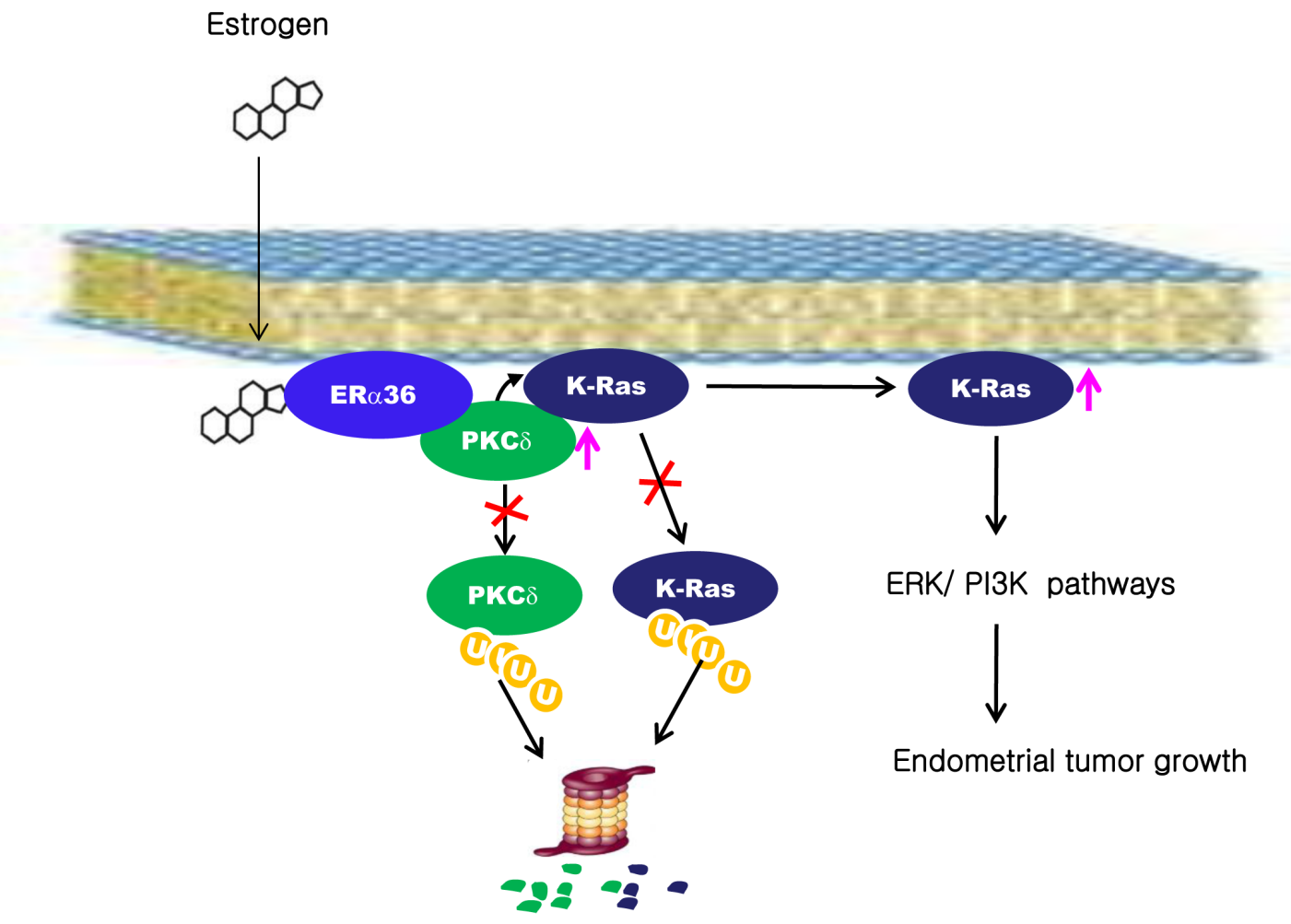

Figure 7: A proposed model for K-Ras stabilization by estrogen in endometrial tumorigenesis. Estrogen stabilizes PKC $\delta$ by inhibiting ubiquitylation-dependent proteasomal degradation. $\mathrm{PKC} \delta$ binds to K-Ras via ER- $\alpha 36$ in a manner dependent upon estrogen and subsequently inhibits K-Ras degradation. The stabilized K-Ras stimulates endometrial tumor growth via the ERK and PI3 kinase signaling pathways. 
with neoplastic transformation.

In this study, we also found that Ras protein levels were high in the proliferative stage of normal endometrium as well as in EC tissues. The Ras isotypes including K-Ras, N-Ras, and H-Ras, were all subjected to stability increments by estrogens via the mechanism involving membraneous ER- $\alpha 36$ followed by activation of PKC $\delta$ (Figure 7).

PKC $\delta$ was specifically involved in the K-Ras stabilization by estrogen and the estrogen-induced K-Ras stabilization was abolished by knockdown of $\mathrm{PKC} \delta$, but not by knockdown of other PKC isotypes. The significance of PKC $\delta$ in K-Ras stabilization by estrogens was indicated by complete abolishment of the estrogen effect by PKC $\delta$ knockdown. Tumors with wild-type Ras and aberrant activation of the PI3K or ERK pathways have been shown to require $\mathrm{PKC} \delta$ activity for proliferation or survival [33], indicating the important role of PKC $\delta$ activity in cellular transformation. We identified that $\mathrm{PKC} \delta$ activity is important in the K-Ras stabilization by estrogens; the stabilization increased through ER- $\alpha 36$ (Figure 7). The ubiquitination assays for both $\mathrm{PKC} \delta$ and $\mathrm{K}$-Ras showed that both of the two proteins were increased via inhibition of polyubiquitylation-dependent proteasomal degradation. Furthermore, PKC $\delta$ activity was shown to be required for the inhibition of ubiquitination and subsequent stabilization of Gadd45, which correlated with the role of $\mathrm{PKC} \delta$ in K-Ras stabilization [34].

The stabilization of K-Ras by estrogens via PKC $\delta$ was correlated with the proliferation and transformation of EC cells as shown by K-Ras and PKC $\delta$ knockdown, respectively. The suppression of the estrogen induced tumor growth of EC cells by the PKC $\delta$ inhibitor rottlerin implicated K-Ras stabilization by estrogens in the growth of EC. Inhibition of the xenograft tumor growth by rottlerin provides in vivo evidence for the role of $\mathrm{PKC} \delta$ in the tumor growth. The role of K-Ras stabilization via PKC $\delta$ was confirmed in vivo by both immunoblot and immunohistochemical analyses of human EC tissues. Our results suggest that $\mathrm{PKC} \delta$ is a potential therapeutic approach for development of anti-cancer drugs for treatment of ECs.

\section{MATERIALS AND METHODS}

\section{Cell lines, culture and reagents}

HEC1A, AN3CA, and KLE cell lines were provided by Dr. Churl Ki Min (Ajou University, Suwon, South Korea), and the RL95-2 cell line was provided by Dr. Jong-Min Kim (Dong-A University, Pusan, Korea). The Ishikawa cell line was a gift from Dr. Hyung Sik Kim (Pusan National University, Pusan, Korea). The EM-E6/ E7/hTERT cell line was originated by Mizumoto and colleagues [35] and obtained from Dr. Paul J. Goodfellow (Ohio State University, Columbus, OH). ECC-1 cells were purchased from the ATCC. All cell lines were maintained in Dulbecco's Modified Eagle Medium: Nutrient Mixture F-12 (DMEM /F12; Gibco) supplemented with 10\% fetal bovine serum (FBS) (Gibco), 1\% penicillin-streptomycin (Gibco) at $37^{\circ} \mathrm{C}$ in a humidified atmosphere of $5 \% \mathrm{CO}_{2}$. For $\mathrm{E}_{2}$ treatment, cells were maintained in phenol redfree DMEM/F12 (Gibco) with 5\% charcoal-stripped FBS for 1 day followed by serum-free medium for 24 $\mathrm{h}$ before the experiment. The $\mathrm{E}_{2}$ and $\mathrm{E}_{2}$-BSA (bovine serum albumin) were purchased from Sigma. $\mathrm{E}_{2}-\mathrm{BSA}$ was prepared according to the protocol for removing free $\mathrm{E}_{2}$ as previously described [36]. Cycloheximide (CHX) and $N$-acetyl-leucinyl-leucinyl-norleucinal (ALLN) were purchased from Sigma.

\section{Establishment of stable cell lines}

shRNA PKC $\delta$ for the stable knockdown of human PKC $\delta$ expression [37] was obtained from Mary E. Reyland (University of Colorado, Denver, CO). Stable knockdown of K-Ras was accomplished using lentiviral constructs containing short hairpin RNA (shRNA) for human $K$-Ras (Sigma). The lentiviral vectors were transfected into HEK$293 \mathrm{~T}$ cells with the packaging plasmids psPAX2 and pMD2.G (a gift from Dr. KunLiang Guan, University of California, San Diego, CA) [38] and using Lipofectamine reagent (Invitrogen). The virus particles were harvested at $24 \mathrm{~h}$ after transfection. Then, fresh media was added to the cells, which were harvested at $48 \mathrm{~h}$. EC cell lines were infected with lentivirus-containing media with polybrene $(8 \mu \mathrm{g} / \mathrm{ml})$ for $6 \mathrm{~h}$, followed by replacement with fresh media. Cell lines were selected in media with puromycin $(1 \mu \mathrm{g} / \mathrm{ml})$. Stable knockdown of human PKC $\delta$ was carried out using lentiviral constructs.

\section{Quantitative real-time PCR}

Total RNA was extracted from cells using TRIzol (Invitrogen). Transcripts were measured by quantitative real-time PCR (qRT-PCR) analysis using the Qiagen StepOnePlus qRT-PCR system according to the manufacturer's instructions (Qiagen). All RT-PCR analyses were performed using five independent RNA sets. The relative expression of each transcript was normalized to $\beta$-actin. The following primer sets were used: $K$-Ras, forward 5'-GTATAGAAGGCATCATCAACAC and reverse 5'-AAACAGGCTCAGGACTTAG; H-Ras, forward 5'-AGACTTGGTGTTGTTGATGG and reverse 5'-GGAAGCAGGTGGTCATTG-3'; N-Ras forward 5'-CCATCATCACTGCTGTTGA-3' and reverse 5'-A AGAGTTACGGGATTCCATTC-3'; $\beta$-actin, forward5'ATAGCACAGCCTGGATAGCAAC- $3^{\prime}$ and reverse 5'-AATCTGGCACCACACCTTCTAC-3'. 


\section{Plasmids and transfection}

The ER- $\alpha 36$-specific shRNA expression vector 231/sh36 (3-1) (\#1), 231/sh36 (1-7) (\#3), control vector expressing shRNA for luciferase 231/shluc, and pCB6-HA-ER- $\alpha 36$ were provided by Dr. Zhaoyi Wang (Creighton University Medical School, Omaha, NE) [39]. pCMV-Flag-ER- $\alpha 36$ was generated by PCR of pCB6-HA-ER- $\alpha 36$ using primer sets (forward 5'-GAATTCAATGGCTATGGAATCTGCC-3' and reverse 5'-GAATTCTTAGACACGAGGAAACCA-3') followed by cloning into pCMV. pCMV-Flag-ER- $\alpha 66$ [40] was provided by Dr. W. Lee Kraus (Cornell University, Ithaca, NY). The sequence coding the nuclear localizing signal (NLS, 250-303 amino acids of ER- $\alpha 66$ ) was deleted with PCR-based sited-directed mutagenesis of the pCMV-FlagER- $\alpha 66$. pHACE plasmids coding for HA-tagged $\mathrm{PKC} \delta$ WT, PKC $\delta$-DN, PKC $\delta$-CA, PKC $\alpha$, PKC $\varepsilon$, and PKC $\zeta[41]$ were provided by Dr. Jang-Soo Chun (Gwangju Institute of Science and Technology, Kwangju, Korea). EC cells were seeded at $60 \mathrm{~mm}$ culture dishes $\left(1 \times 10^{5}\right.$ cells $)$ and culture for $24 \mathrm{~h}$ before transfection. Transfection of plasmids was performed with Lipofectamine according to the manufacturer's instructions.

\section{In vivo ubiquitylation assay and immunoblot analysis}

In vivo ubiquitylation assays and immunoblot analyses were performed as previously described [19]. Briefly, N-ethylmaleimide (10 mM, Sigma) was added to the radioimmunoprecipitation assay (RIPA) buffer (Upstate Biotechnology). The lysates were incubated with the indicated antibodies and Protein $G$ agarose at $4^{\circ} \mathrm{C}$ for $12 \mathrm{~h}$, and the beads were washed three times with cold RIPA buffer. Immunoblot analysis was performed as previously described [19]. Primary antibodies were obtained from the following sources; anti-pan-Ras (Millipore); -K-Ras, -N-Ras, -H-Ras, - $\beta$-actin, -p-ERK, -p-AKT, -PKC $\delta,-P K C \alpha,-P C N A$, and -c-Myc (Santa Cruz Biotechnology); -HA, -PKC $\varepsilon$, and $-\mathrm{PKC} \zeta$ (Cell Signaling Technology); -Flag (Sigma); and -ER- $\alpha 36$ (Cell Applications). Secondary antibodies were horseradish peroxidase (HRP)-conjugated anti-mouse (Cell Signaling Technology) and HRP-conjugated anti-rabbit (Bio-Rad).

\section{MTT and focus formation assays}

For the MTT assay, cells were plated at 24-well plate $\left(1.7 \times 10^{4}\right.$ cells $)$ and treated with/without $\mathrm{E}_{2}$ for $72 \mathrm{~h}$. MTT reagent (3-(4,5-dimethylthiazol-2-yl)-2,5diphenyltetrazolium bromide; AMRESCO) was diluted in phenol red-free DMEM/F12 at a concentration of 0.25 $\mathrm{mg} / \mathrm{ml}$. Cells were incubated for $2 \mathrm{~h}$ at $37^{\circ} \mathrm{C}$. Medium was removed and insoluble formazan was solubilized with $500 \mu \mathrm{l}$ dimethyl sulfoxide (DMSO; Sigma) for $30 \mathrm{~min}$. Formazan product absorbance was determined at $420 \mathrm{~nm}$.

For focus formation assay, cells were seeded at 12well plate $\left(500\right.$ cells). The cells were treated with $\mathrm{E}_{2}$ in phenol red-free DMEM/F12 for 14 days, and in case of Ishikawa cells, $0.5 \%$ charcoal-stripped FBS was added. Media were changed at every 3 days. After 14 days, cells were stained with $0.5 \%$ crystal violet in $20 \%$ ethanol.

\section{In vivo tumor xenograft assay}

Approximately 5-week-old female Balb Cnu/nu mice were purchased from Orientbio Inc. (Seongnam, Korea). Mice were maintained as previously described [42]. An $\mathrm{E}_{2}$ pellet $(1.7 \mathrm{mg} / 60$-day release; Innovative Research of America) was implanted subcutaneously before the injection of Ishikawa cells. Five days later, Ishikawa cells $\left(1.5 \times 10^{7}\right)$ in $100 \mu \mathrm{L}$ of DMEM/ F12:Matrigel (1:1) were subcutaneously injected into the dorsal flank of each mouse. Two days later, $5 \mathrm{mg} / \mathrm{kg}$ of rottlerin in DMSO was administered intraperitoneally to the mice daily for 22 days, and the control mice were given DMSO in the same manner. Tumor volumes and body weights of mice were measured at every 3 days. Tumors were measured with Vernier calipers, and tumor volumes were calculated by the formula $\pi / 6 \times$ length $\times$ width $\times$ height . The mice were sacrificed under anesthesia, and the tumors were collected for further analysis.

\section{Immunohistochemical analysis}

Tumor samples were fixed in $4 \%$ paraformaldehydefixed and embedded in paraffin wax according to standard procedures. Tissue sections $(4 \mu \mathrm{m}$ each) were deparaffinized in xylene and dehydrated through a gradient concentration of alcohol. For antigen retrieval, the slides were autoclaved in buffer ( $10 \mathrm{mM}$ sodium citrate $\mathrm{pH} 6.0$, Sigma-Aldrich). Sections were preincubated in phosphatebuffered saline (PBS) and then blocked with 5\% BSA in PBS for $30 \mathrm{~min}$ at room temperature. The sections were incubated with the following primary antibodies overnight at $4^{\circ} \mathrm{C}$ : anti-pan-Ras (1:100, Millipore), $-\mathrm{PKC} \delta$ (1:100, Santa Cruz Biotechnology), -PCNA (1:1000, Santa Cruz Biotechnology)-c-MYC (1:100, Santa Cruz Biotechnology) -p-ERK (1:20, Cell Signaling Technology, -p-Akt (1:20, Cell Signaling Technology).

For immunofluorescence staining, the sections were then incubated with Alexa Fluor 488- or Alexa Fluor 555-conjugated secondary antibodies (Invitrogen) at room temperature for $1 \mathrm{~h}$ followed by counterstaining with 4',6-diamidino-2-phenylindole (DAPI) (Boehringer Mannheim) and mounted in Gel/Mount medium (Biomeda Corporation). Visualization of the fluorescence signal was performed by confocal microscopy (Carl Zeiss LSM700, 
Oberkochen, Germany).

Tissue Microarrays (TMAs) for normal and cancerous endometrial tissues were purchased from US Biomax. For immunoperoxidase staining, endogenous peroxidase was blocked with $0.345 \% \mathrm{H}_{2} \mathrm{O}_{2}$ (Samchun Chemicals, Pyeongtaek, Korea) for $15 \mathrm{~min}$, followed by incubation with biotin-conjugated secondary antibodies for $1 \mathrm{~h}$ at room temperature, washing and incubation with an Avidin-Biotin complex (Vector Laboratories) for 30 $\mathrm{min}$. The brown color indicative of peroxidase activity was developed by 3, 3-incubating with diaminobenzidine (DAB) staining solution (Vector Laboratories) followed by counter staining with Mayer's hematoxylin (Muto Chemicals, Tokyo, Japan). The DAB-stained preparations were visualized with a Nikon bright-field microscope (Nikon TE-2000U, Tokyo, Japan). Relative staining intensities were quantified using HistoQuest software (TissueGnostics, Vienna, Austria).

\section{Statistical analysis}

Data are presented as mean \pm standard deviation. Student's t-test was performed using Microsoft Excel spreadsheets and GraphPad Prism. Statistical significance is indicated in the figures as follows: ${ }^{*} P<0.05,{ }^{* *} P<$ 0.01 , and $* * * P<0.005$.

\section{ACKNOWLEDGMENTS}

This work was supported by the National Research Foundation (NRF), the Ministry of Future Creation and Science (MFCS) of Korea through the Mid-Career Researcher Program National Leading Research Lab (2012-010285), the Translational Research Center for Protein Function Control (2009-0092955). K.-H. Koo, W.-J. Jeong, Y.-H. Cho, and J.-C. Park were supported by a BK21 studentship.

The authors thank Dr. Churl Ki Min for providing the HEC1A, AN3CA, and KLE cell lines, Dr. Jong-Min Kim for the RL95-2 cell, Dr. Hyung Sik Kim for the Ishikawa cell line, and Dr. Paul J. Goodfellow for the EME6/E7/hTERT cell line.

\section{CONFLICT OF INTEREST STATEMENT}

The authors declare that no potential conflict of interest exists.

\section{REFERENCES}

1. Bokhman JV. Two pathogenetic types of endometrial carcinoma. Gynecol Oncol. 1983; 15:10-17.

2. Llobet D, Pallares J, Yeramian A, Santacana M, Eritja N, Velasco A, Dolcet X, Matias-Guiu X. Molecular pathology of endometrial carcinoma: practical aspects from the diagnostic and therapeutic viewpoints. J Clin Pathol. 2009; 62:777-785.

3. Cade TJ, Quinn MA, Rome RM, Neesham D. Progestogen treatment options for early endometrial cancer. BJOG. 2010; 117:879-884

4. Cohlen B, Cantineau A, D'Hooghe T, te Velde E. Multiple pregnancy after assisted reproduction. Lancet. 2005; 366:452-453; author reply 453-454.

5. Lepine J, Audet-Walsh E, Gregoire J, Tetu B, Plante M, Menard V, Ayotte P, Brisson J, Caron P, Villeneuve L, Belanger A, Guillemette C. Circulating estrogens in endometrial cancer cases and their relationship with tissular expression of key estrogen biosynthesis and metabolic pathways. J Clin Endocrinol Metab. 2010; 95:2689-2698.

6. Berstein LM, Tchernobrovkina AE, Gamajunova VB, Kovalevskij AJ, Vasilyev DA, Chepik OF, Turkevitch EA, Tsyrlina EV, Maximov SJ, Ashrafian LA, Thijssen JH. Tumor estrogen content and clinico-morphological and endocrine features of endometrial cancer. J Cancer Res Clin Oncol. 2003; 129:245-249.

7. McDonnell DP, Norris JD. Connections and regulation of the human estrogen receptor. Science. 2002; 296:16421644.

8. Hall JM, Couse JF, Korach KS. The multifaceted mechanisms of estradiol and estrogen receptor signaling. J Biol Chem. 2001; 276:36869-36872.

9. Klinge CM, Blankenship KA, Risinger KE, Bhatnagar S, Noisin EL, Sumanasekera WK, Zhao L, Brey DM, Keynton RS. Resveratrol and estradiol rapidly activate MAPK signaling through estrogen receptors alpha and beta in endothelial cells. J Biol Chem. 2005; 280:7460-7468.

10. Lin SL, Yan LY, Zhang XT, Yuan J, Li M, Qiao J, Wang ZY, Sun QY. ER-alpha36, a variant of ER-alpha, promotes tamoxifen agonist action in endometrial cancer cells via the MAPK/ERK and PI3K/Akt pathways. PLoS One. 2010; 5:e9013.

11. Kang L, Zhang X, Xie Y, Tu Y, Wang D, Liu Z, Wang ZY. Involvement of estrogen receptor variant ER-alpha36, not GPR30, in nongenomic estrogen signaling. Mol Endocrinol. 2010; 24:709-721.

12. Tong JS, Zhang QH, Wang ZB, Li S, Yang CR, Fu XQ, Hou Y, Wang ZY, Sheng J, Sun QY. ER-alpha36, a novel variant of ER-alpha, mediates estrogen-stimulated proliferation of endometrial carcinoma cells via the PKCdelta/ERK pathway. PLoS One. 2010; 5:e15408.

13. Basu A, Pal D. Two faces of protein kinase Cdelta: the contrasting roles of PKCdelta in cell survival and cell death. ScientificWorldJournal. 2010; 10:2272-2284.

14. Fujimoto J, Hori M, Ichigo S, Morishita S, Tamaya T. Clinical implication of fos and jun expressions and protein kinase activity in endometrial cancers. Eur J Gynaecol Oncol. 1995; 16:138-146.

15. Scambia G, Catozzi L, Benedetti-Panici P, Ferrandina G, Battaglia F, Giovannini G, Distefano M, Pellizzola D, 
Piffanelli A, Mancuso S. Expression of ras p21 oncoprotein in normal and neoplastic human endometrium. Gynecol Oncol. 1993; 50:339-346.

16. Yun MS, Kim SE, Jeon SH, Lee JS, Choi KY. Both ERK and Wnt/beta-catenin pathways are involved in Wnt3ainduced proliferation. J Cell Sci. 2005; 118:313-322.

17. Park KS, Jeon SH, Kim SE, Bahk YY, Holmen SL, Williams BO, Chung KC, Surh YJ, Choi KY. APC inhibits ERK pathway activation and cellular proliferation induced by RAS. J Cell Sci. 2006; 119:819-827.

18. Jeon SH, Yoon JY, Park YN, Jeong WJ, Kim S, Jho EH, Surh YJ, Choi KY. Axin inhibits extracellular signalregulated kinase pathway by Ras degradation via betacatenin. J Biol Chem. 2007; 282:14482-14492.

19. Kim SE, Yoon JY, Jeong WJ, Jeon SH, Park Y, Yoon JB, Park YN, Kim H, Choi KY. H-Ras is degraded by Wnt/beta-catenin signaling via beta-TrCP-mediated polyubiquitylation. J Cell Sci. 2009; 122:842-848.

20. Jeong WJ, Yoon J, Park JC, Lee SH, Lee SH, Kaduwal S, Kim H, Yoon JB, Choi KY. Ras stabilization through aberrant activation of Wnt/beta-catenin signaling promotes intestinal tumorigenesis. Sci Signal. 2012; 5:ra30.

21. Moon BS, Jeong WJ, Park J, Kim TI, Min do S, Choi KY. Role of oncogenic K-Ras in cancer stem cell activation by aberrant Wnt/beta-catenin signaling. J Natl Cancer Inst. 2014; 106:djt373.

22. Jiang F, Liu T, He Y, Yan Q, Chen X, Wang H, Wan X. MiR-125b promotes proliferation and migration of type II endometrial carcinoma cells through targeting TP53INP1 tumor suppressor in vitro and in vivo. BMC Cancer. 2011; $11: 425$.

23. Wang Z, Zhang X, Shen P, Loggie BW, Chang Y, Deuel TF. A variant of estrogen receptor- $\{$ alpha $\}$, hER- $\{$ alpha $\} 36$ : transduction of estrogen- and antiestrogen-dependent membrane-initiated mitogenic signaling. Proc Natl Acad Sci U S A. 2006; 103:9063-9068.

24. Kato K, Ueoka Y, Kato K, Hachiya T, Nishida J, Wake N. Contribution of enhanced transcriptional activation by ER to [12Val] K-Ras mediated NIH3T3 cell transformation. Oncogene. 1997; 15:3037-3046.

25. Mizumoto Y, Kyo S, Kiyono T, Takakura M, Nakamura M, Maida Y, Mori N, Bono Y, Sakurai H, Inoue M. Activation of NF-kappaB is a novel target of KRASinduced endometrial carcinogenesis. Clin Cancer Res. 2011; 17:1341-1350.

26. Campbell PM, Groehler AL, Lee KM, Ouellette MM, Khazak V, Der CJ. K-Ras promotes growth transformation and invasion of immortalized human pancreatic cells by Raf and phosphatidylinositol 3-kinase signaling. Cancer Res. 2007; 67:2098-2106.

27. Krens LL, Baas JM, Gelderblom H, Guchelaar HJ. Therapeutic modulation of k-ras signaling in colorectal cancer. Drug Discov Today. 2010; 15:502-516.

28. Thomas RK, Baker AC, Debiasi RM, Winckler W,
Laframboise T, Lin WM, Wang M, Feng W, Zander T, MacConaill L, Lee JC, Nicoletti R, Hatton C, et al. Highthroughput oncogene mutation profiling in human cancer. Nat Genet. 2007; 39:347-351.

29. Murali R, Soslow RA, Weigelt B. Classification of endometrial carcinoma: more than two types. Lancet Oncol. 2014; 15:e268-278.

30. Prior IA, Hancock JF. Ras trafficking, localization and compartmentalized signalling. Semin Cell Dev Biol. 2012; 23:145-153.

31. Dati C, Muraca R, Tazartes O, Antoniotti S, Perroteau I, Giai M, Cortese P, Sismondi P, Saglio G, De Bortoli M. c-erbB-2 and ras expression levels in breast cancer are correlated and show a co-operative association with unfavorable clinical outcome. Int J Cancer. 1991; 47:833838.

32. Konishi N, Enomoto T, Buzard G, Ohshima M, Ward JM, Rice JM. K-ras activation and ras p21 expression in latent prostatic carcinoma in Japanese men. Cancer. 1992; 69:2293-2299.

33. Chen Z, Forman LW, Miller KA, English B, Takashima A, Bohacek RA, Williams RM, Faller DV. Protein kinase Cdelta inactivation inhibits cellular proliferation and decreases survival in human neuroendocrine tumors. Endocr Relat Cancer. 2011; 18:759-771.

34. Leung CH, Lam W, Zhuang WJ, Wong NS, Yang MS, Fong WF. PKCdelta-dependent deubiquitination and stabilization of Gadd45 in A431 cells overexposed to EGF. Biochem Biophys Res Commun. 2001; 285:283-288.

35. Mizumoto Y, Kyo S, Ohno S, Hashimoto M, Nakamura M, Maida Y, Sakaguchi J, Takakura M, Inoue M, Kiyono T. Creation of tumorigenic human endometrial epithelial cells with intact chromosomes by introducing defined genetic elements. Oncogene. 2006; 25:5673-5682.

36. Taguchi Y, Koslowski M, Bodenner DL. Binding of estrogen receptor with estrogen conjugated to bovine serum albumin (BSA). Nucl Recept. 2004; 2:5.

37. Symonds JM, Ohm AM, Carter CJ, Heasley LE, Boyle TA, Franklin WA, Reyland ME. Protein kinase C delta is a downstream effector of oncogenic K-ras in lung tumors. Cancer Res. 2011; 71:2087-2097.

38. Lian I, Kim J, Okazawa H, Zhao J, Zhao B, Yu J, Chinnaiyan A, Israel MA, Goldstein LS, Abujarour R, Ding $\mathrm{S}$, Guan KL. The role of YAP transcription coactivator in regulating stem cell self-renewal and differentiation. Genes Dev. 2010; 24:1106-1118.

39. Zhang XT, Kang LG, Ding L, Vranic S, Gatalica Z, Wang ZY. A positive feedback loop of ER-alpha36/EGFR promotes malignant growth of ER-negative breast cancer cells. Oncogene. 2011; 30:770-780.

40. Cheung E, Zarifyan AS, Kraus WL. Histone H1 represses estrogen receptor alpha transcriptional activity by selectively inhibiting receptor-mediated transcription initiation. Mol Cell Biol. 2002; 22:2463-2471. 
41. Soh JW, Lee EH, Prywes R, Weinstein IB. Novel roles of specific isoforms of protein kinase $\mathrm{C}$ in activation of the c-fos serum response element. Mol Cell Biol. 1999; 19:1313-1324.

42. Yoon J, Koo KH, Choi KY. MEK1/2 inhibitors AS703026 and AZD6244 may be potential therapies for KRAS mutated colorectal cancer that is resistant to EGFR monoclonal antibody therapy. Cancer Res. 2011; 71:445453. 